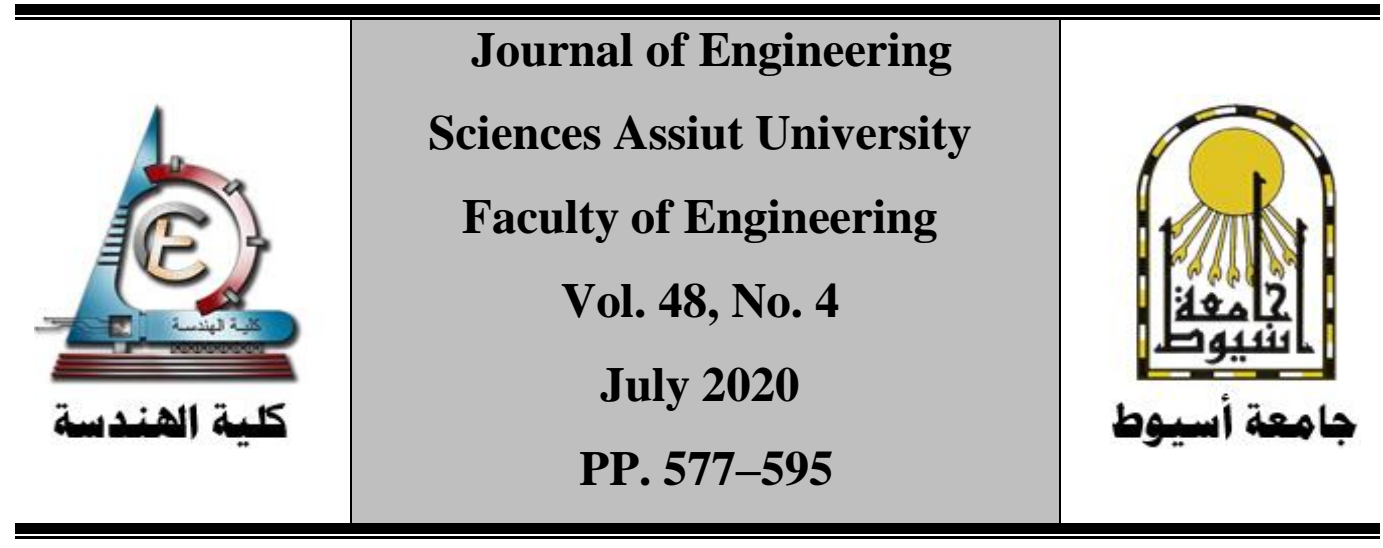

\title{
INCREASING THE EFFICIENCY OF THE RIVER NILE WESTERN BRANCH AT WARRAK ISLAND
}

\author{
Radwa Salama* $^{*}$, Mohammed Ghareeb ${ }^{2}$, Shaimaa El Sherbini ${ }^{3}$ \\ ${ }^{1,2,3}$ Nile research Institute (NRI), National Water Research Center (NWRC), Egypt \\ *radwa.salama@yahoo.com
}

Received 26 June 2020; Revised 10 August 2020; Accepted 13 August 2020

\begin{abstract}
Regulated rivers usually subjected to continuous morphological changes due to human interventions and the variation of the flow rates released through them. These changes sometimes affect island banks causing bank failure and deformation. On the other hand, the morphological changes cause the riverbed to aggrade/degrade. This, in turn, may affect the carrying capacity and conveyance of the river channel. To keep the channel conveyance as efficient as possible, bed aggradation should be minimized. This paper basically aims at increasing the efficiency of the River Nile western branch at Warrak Island. Eight scenarios are proposed to achieve this goal, which includes removing the unmanaged human intervention at the island southern nose, dredging the western branch to the safe navigation elevation $(12.66 \mathrm{~m})$ and propose a development plan for canalization of this branch. A 2-D numerical model (Delft 3D) was used to simulate this segment of the river to detect and predict the trend of the morphological changes. The ratio of flow passes through this branch is calculated for all cases, it was found to be $31.4 \%$ for the current case, while the maximum value of $45.52 \%$ occurred when removing of the southern part of the island nose and dredging the branch is applied. The morphological changes were predicted, and it is found that the entrance of the west branch is always subjected to sedimentation due to the general alignment of the river in this region. Results also indicates, for development scenarios, that deposition also occurred in the entrance of the west branch, like before, but the dredging was limited to few locations, which can be handled with dredging. So, it is
\end{abstract}


recommended, in case of using the west branch for navigation in an emergency case, to follow the development of the west branch as a solution.

KEYWORDS: Morphological changes; River Nile; Warrak Island; Delft 3D; Sedimentation and Dredging.

\section{Introduction}

The morphology of River Nile is exposed to continuous changes, such as bank failure, bed erosion and deposition, and new island formation. These changes produced from man-made interference which affects river hydraulic characteristics. Islands are generally dividing the flow into two branches in their locations, the main branch is considered the one which has, in most cases, the greater discharge. The secondary branch is characterized by small depths, and it may be subjected to deposition of sediments. These sediments can contribute, by the time, in decreasing the flow passes through the branch. The human interventions, in rivers, can be related to banks such as bank protection or backfilling the lowlands to increase its level to be used as agricultural land all over the year.

Fluvial islands are defined as a mass of land inside a river which is separated from the floodplain or riverbank by water on all sides [1]. the fluvial islands were formed because of the deposition of the coarse material from the suspended load. The island formed because of the less ability of the river to move the bed load. It has collected to form the early of the island after that it received the amount of the soft deposits [2]. The island development of Farser River, British Columbia, Canada, during the twentieth century indicates that the filing of the secondary channel is a trend in a long-term situation. While the cross-section area of the main and principal channel was increased [3]. Generally, the total number of islands are decreased after the operation of the High Aswan Dam. Several islands were merged with other or declined due to erosion or merging with banks. In addition, Human interference contributes to changes in island development [4]. The morphological unbalance resulted from morphological changes can result in an unfavorable condition causes the river channel to be blocked or to be subjected to aggradation. This aggradation causes a "navigational bottlenecks", which causes a complete stop for navigation movements [5]. 
The hydrological changes of the River Nile between 1982 and 2004 indicates that a drop in water level occurs which explained as a riverbed degradation and aggradation, where aggradation occurs in some location due to narrowing cross-section by backfilling and encroachments [6]. The floating weeds can contribute to aggradation and degradation process by changing the velocity profiles in both longitudinal and transverse sections and eventually help in temporary island formation [7].

The impact of developing Shubra El-Khaima Island, located as a part of the study reach in the east branch, was studied using a dimensional model (GSTAR 3.0 ) on the morphology of the Nile. While an aggradation effect of a maximum $3.4 \mathrm{~m}$ and degradation of $0.7 \mathrm{~m}$ occurs in the study reach [8].

Warrak island is considered one of the oldest islands found in the River Nile, it was subjected to unmanaged human interventions in the 1990s, represented in backfilling the southern part of the island with protecting the nose of the island. The west branch now receives a flow ratio less than the east [8], which decreases the carrying capacity of it, and in recent years it is noted that the west branch is subject to sedimentation, especially at its entrance. The accumulation of aquatic weeds in the river channel resulted in decreasing the width of river section [9]. The area of aquatic weeds in the west channel equal to $33.7 \%$ of the total area of the west channel for the island which are be taken in reducing the area of the watercourse.

The main goal of this paper is to increase the west channel efficiency by increasing flow ratio and the carrying capacity of the western branch by applying different alternatives such as removing the southern part of the island and/or dredging the west channel. Increasing the efficiency of the west channel contribute of decreasing the sedimentation at this branch, and hence it may be used for navigation in an emergency situation, also, it will contribute in decreasing the sedimentation at different water station intakes found along the west bank.

\section{Study Area Characteristics}

The Main Nile River in Egypt is divided into four Reaches; the first one is bounded by Old Aswan Dam and Esna Barrage, while the second from Esna Barrage to Naga Hammadi Barrage, the third reach is lies between Naga Hammadi Barrage and Assuit Barrage. Warrak Island lies in the fourth Reach which bounded by Assuit Barrage and Delta Barrage as shown in Figure (1). 
Warrak Island (Permanent Island) is considered one of the oldest and largest islands in the River Nile in the region of Greater Cairo in the backwater curve region of Delta Barrage [8]. It is extended from $\mathrm{km}(1 \cdot .00)$ to $\mathrm{km}(17.00)$ downstream Roda Gauge. There are many canal intakes located along east side of the study area such as Ismailia and Sharkawia canals, in addition to AboElmenaga pump station. The river in the upstream part of the study area flows in a straight path towards the northeast direction where it makes an angle of 30 degrees with the north direction. Many bridges are crossing the Nile River in the study area, such as Rode El-Farage Bridge at the upstream end of the study area, also, the ring road bridge near the downstream end of the island. Recently, the Tahya Misr Bridge was constructed near the upstream end of the island. All these features will contribute to morphological changes in the study area.

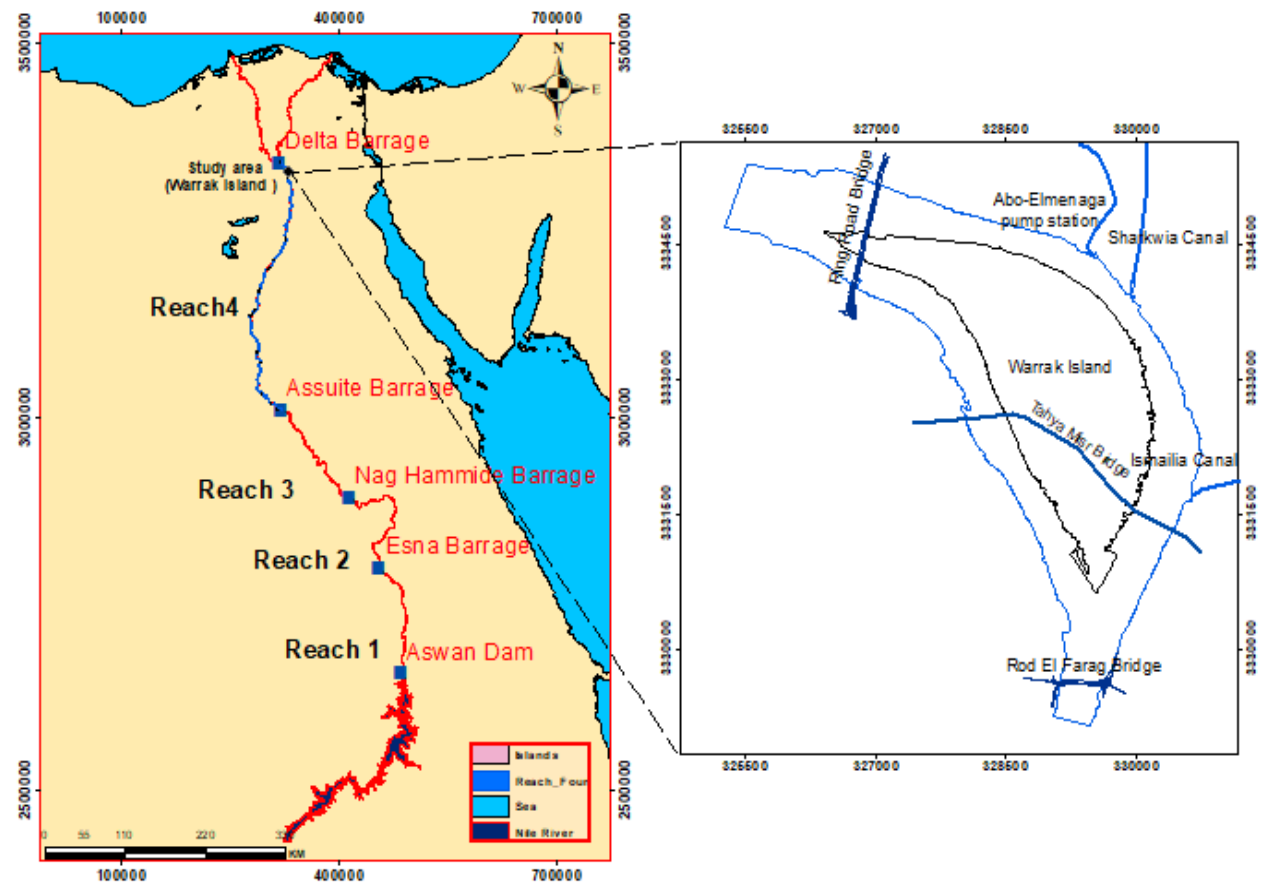

Fig. 1. Study Area

The western branch around Warrak Island is considered as the secondary branch while the main is the eastern one. The average width of the east branch is about $450 \mathrm{~m}$, while the west branch is $250 \mathrm{~m}$. The ratio of flow passing through each branch is affected by morphological factors such as river width, depth, and alignment. In addition, it can be affected by man-made developments.

The shape and alignment of Warrak Island are relatively constant over the latest 200 years or more, Figure (1) shows the status of the island for different time periods. The first known map for Warrak Island was created during the 
French military expedition to Egypt as in Figure (2a). Figure (2b) shows the status of the island after about one hundred years in 1912 [10]. The shape of the island had the same general alignment, but both branches around the island were decreased in width, in addition, other change had been observed for the main banks of the Nile. The current shape of the island is indicated in Figure (2c) [11].

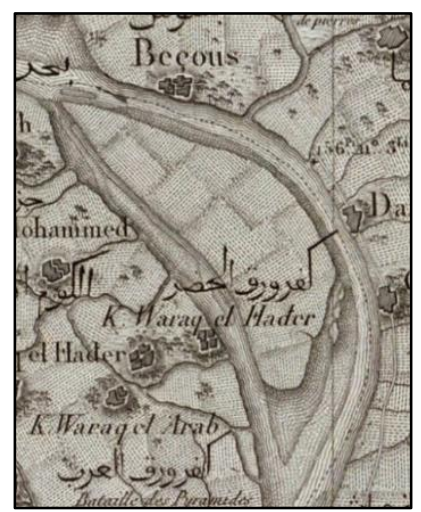

a) 1818

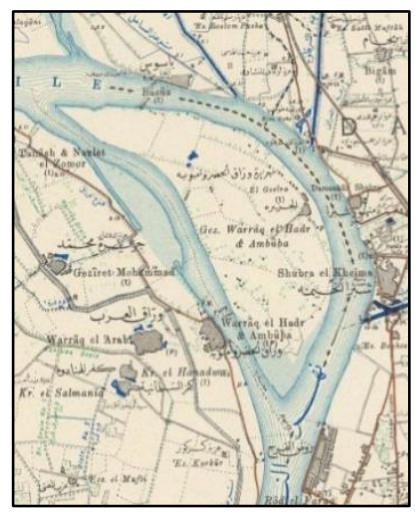

b) 1912

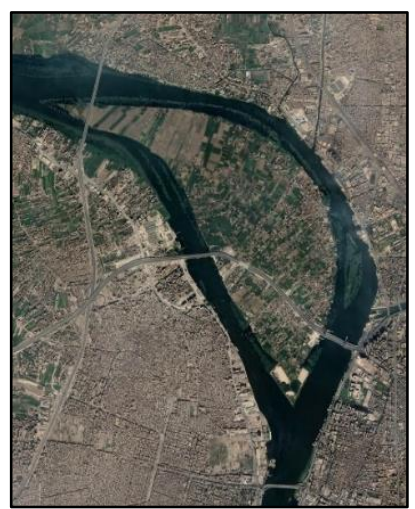

c) 2019

Fig. 2. Warrak Island over 200 years [10], [11]

Generally, the shape of the island is not having a major difference, except for the south part of the island, as it had been lined and banks were protected using rock during the 1990s in order to utilize the select area with a Hospitalization center. So, the development of the island and its impact on the river Nile is considered as an important issue, where some development projects have been established in the region. Also, the region will be subjected to future developments that will maximize the benefit from the island and increase the national income.

\section{Methodology and Data Collection}

To fulfill the main objectives of this research, a field mission was performed to collect the essential data needed for mathematical model calibration. The description of the methodology, the collected data, and the mathematical model is described below.

\subsection{Methodology}

Mathematical modelers usually use the field data in constructing, calibrating, and verifying their hydrodynamic and morphological simulations, while the historically recorded data can be used to put different scenarios of 
flow cases. So, the current study has three stages, 1) data collection, 2) model construction and calibration, and 3) studied scenarios. The flow chart is given in Figure (3) briefly illustrates these stages and what is needed in each stage.

\begin{tabular}{|c|c|c|}
\hline Data Collection & Model Setup & Studied Scenarios \\
\hline & & \\
\hline \begin{tabular}{|l} 
Hydro-topographic maps \\
- Contour Maps 1982 \\
- Contour Maps 2003 \\
- Hydrographic survey \\
2019 \\
Hydraulic Data \\
- Velocity measurements \\
- Bed materials \\
Hydrological Data \\
- Water level \\
- Discharge
\end{tabular} & $\begin{array}{l}\square \text { Grid generation } \\
\square \text { Calibration } \\
\text { - Current bathymetery } \\
\text { - Boundary conditions } \\
\text { - Bed Roughness }\end{array}$ & $\begin{array}{l}\square \text { Hydrodyanmic } \\
\text { Simulations } \\
\text { - With dredging of west } \\
\text { branch } \\
\text { - Without dredging of } \\
\text { west branch } \\
\square \text { Morphological } \\
\text { Simulations } \\
\text { - Best hydrodynamic } \\
\text { scenario } \\
\text { - Developement senarios }\end{array}$ \\
\hline
\end{tabular}

Fig. 3. Flow chart of modeling stages of Warrak Island study

The following methodology will be used through this research:

1- Use the bathymetric data to track the changes in the bed levels in the nose of the Warrak Island because of the interventions that occurred to this part.

2- Construction and calibration of a 2-D mathematical model using Delft 3D for the reach from $\mathrm{km} 8.850$ to $\mathrm{km} 17.000$ downstream El-Roda gauge station, which includes Warrak Island.

3- The carrying capacity will be estimated for the current case (calibration case).

4- To increase the carrying capacity of the west channel, dredging of the west branch will be tested.

5- In addition, three scenarios for removal of the southern part will be tested. The removal scenarios include remove of the southern nose of the island, remove the east part of the island nose only and remove the western part of the island nose only.

6- The effect of the southern part removal will be studied in both the dredging case and in the original bed case.

7- A development plan for the western branch was proposed and simulated using the hydrodynamic model. The development plan is represented in canalization of the western branch, i.e., backfilling the shallow area along the branch.

8- The flow ratio of the west and east branch will be estimated for each scenario. 
9- Sediment transport will be studied for the scenario that resulted in increasing the flow ratio for the west branch to evaluate its future impacts on the western branch and whether it will be morphologically stable or the sedimentation will occur again.

Figure (4) shows the different scenarios that will be studied through this research. All simulation scenarios are presented in detail in Table (1).

Table: 1. The new alternative solutions plan for Warrak Island

\begin{tabular}{|l|l|l|c|c|c|c|}
\hline No & $\begin{array}{l}\text { Alternative } \\
\text { proposed }\end{array}$ & $\begin{array}{l}\text { Remove the } \\
\text { southern } \\
\text { part }\end{array}$ & $\begin{array}{l}\text { Remove } \\
\text { the east }\end{array}$ & $\begin{array}{l}\text { Remove } \\
\text { the west } \\
\text { removing the } \\
\text { southern part } \\
\text { (calibration) }\end{array}$ & $\begin{array}{l}\text { Development } \\
\text { of west } \\
\text { channel }\end{array}$ \\
\hline 1 & $\begin{array}{l}\text { With dredging } \\
\text { the west channel }\end{array}$ & $\mathrm{S}_{1}$ & $\mathrm{~S}_{2}$ & $\mathrm{~S}_{3}$ & $\mathrm{~S}_{7}$ & $\mathrm{D}_{1}$ \\
\hline 2 & $\begin{array}{l}\text { Without } \\
\text { dredging the } \\
\text { west channel }\end{array}$ & $\mathrm{S}_{4}$ & $\mathrm{~S}_{5}$ & $\mathrm{~S}_{6}$ & $\mathrm{~S}_{\text {cal }}$ & $\mathrm{D}_{2}$ \\
\hline
\end{tabular}

Where: S: scenarios and D: Development

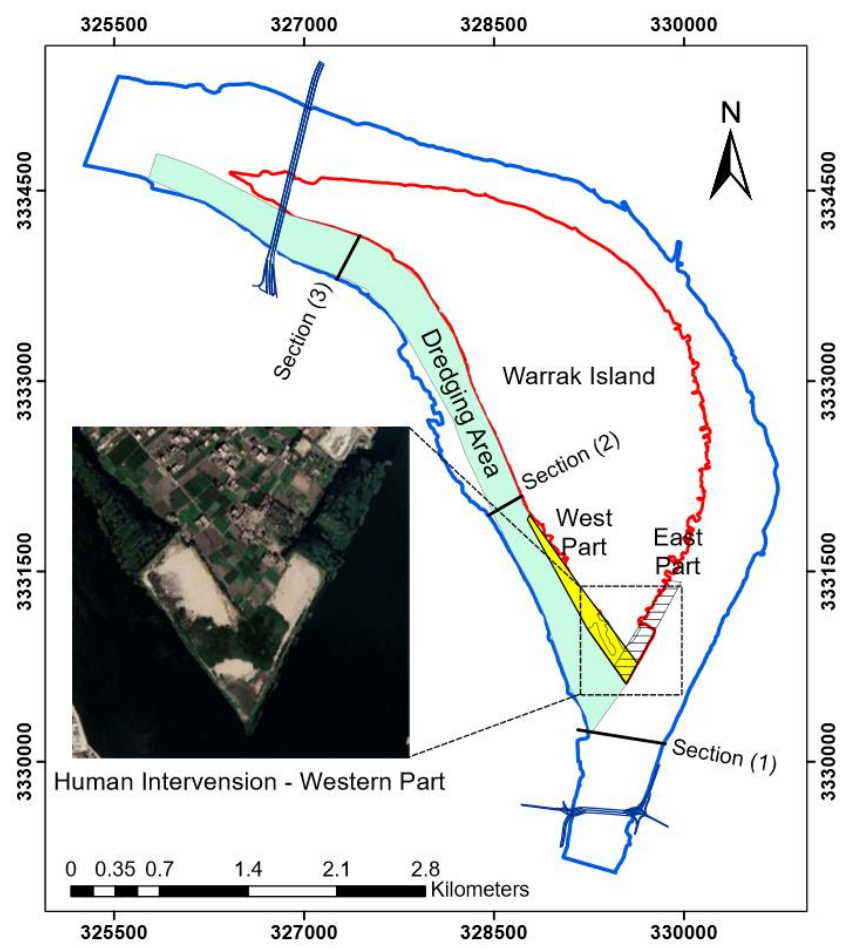

Fig. 4. The alternative proposed areas for scenarios human intervention

\subsection{Data Collection}

Three datasets for bathymetry of the study area were available at Nile Research Institute, the first and the second datasets are contour maps created 
for Nile bed in 1982 and 2003 respectively, while the third dataset is a hydrographic survey for the study area preformed in 2019. Table (2) shows all the available data used to set up the hydrodynamic model.

Table: 2. List of collected data

\begin{tabular}{|l|l|l|}
\hline Data & Location D.S. Roda gauge & Period \\
\hline $\begin{array}{l}\text { Maps (Hydro topography) } \\
\text { (Google Earth) }\end{array}$ & Km 9.000 to Km 17.000 & $2003-2019$ \\
\hline $\begin{array}{l}\text { Discharge (million } \\
\mathrm{m}^{3} / \text { day) }\end{array}$ & D.S. Assuit barrage & $2000-2010$ \\
\hline Water Level (m) & El-Roda and El Kanater & $2000-2010$ \\
\hline Velocity (m/s) & $\begin{array}{l}\text { At km 9.550 at the main channel } \\
\text { and Km 11.760, 14.570 at west branch }\end{array}$ & 2006 \\
\hline Sediment & At km 10.890 and 11.550 & 2010 \\
\hline
\end{tabular}

The water levels were collected and analyzed at different gauge stations along the fourth reach through the period 2000 to 2010. Also, the monthly discharges downstream Assuit Barrage was collected during the same period as in Figure (5a). The pattern of both water level and discharge will be used as an input for the future flow time series for the next ten years, from 2010 to 2020 , to predict the morphological changes that occurred for the study reach as an effect of proposed scenarios as in Figure (5b).

Bed materials samples along the study reach were collected by the researcher, during field trip, from the eastern and western channel at 3 sites (west, middle, and east) across each cross-section. The samples were analyzed to get the grain size distributions of the suspended and bed material load sediments; the bed material of the eastern channel at 10.890 and 11.550 is consisting of medium to fine sand. The fine sand is ranged from $14.96 \%$ to $44.41 \%$ and the percentage of silt is ranged between $0.07 \%$ and $1.15 \%$. Figure (6) illustrates the grain size accumulation curves of the bed material samples at $\mathrm{km} 10.890$ and 11.550. The average $\mathrm{D}_{50}$ ranged from 0.20 to 0.27 .

\subsection{Delft Model Description}

\subsubsection{Mathematical formulation}

The hydrodynamic Delft3D-flow module solves the unsteady shallow water equations (Navier Strokes equations for an incompressible fluid, combined with the shallow water and Boussinesq assumptions) in two (depth average) or three dimensions. This set of equations is based on the continuity and momentum balance principles. The depth and density averaged continuity equation (neglecting precipitation and evaporation) are given in equation 1 , while the depth and density averaged momentum equations (in $\mathrm{x}-$ And $\mathrm{y}$ direction, respectively) are given in equations 2 and 3 [12]. 


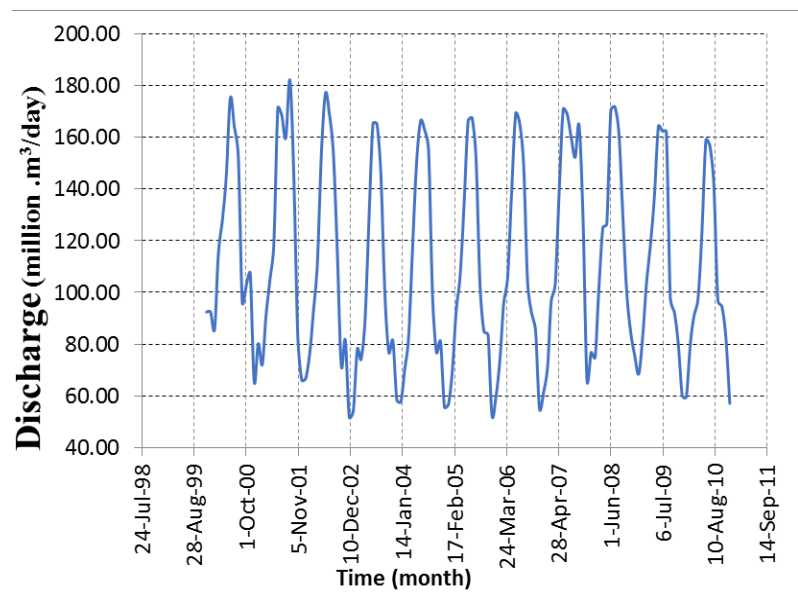

a) Discharge D.S. Assuit Barrage

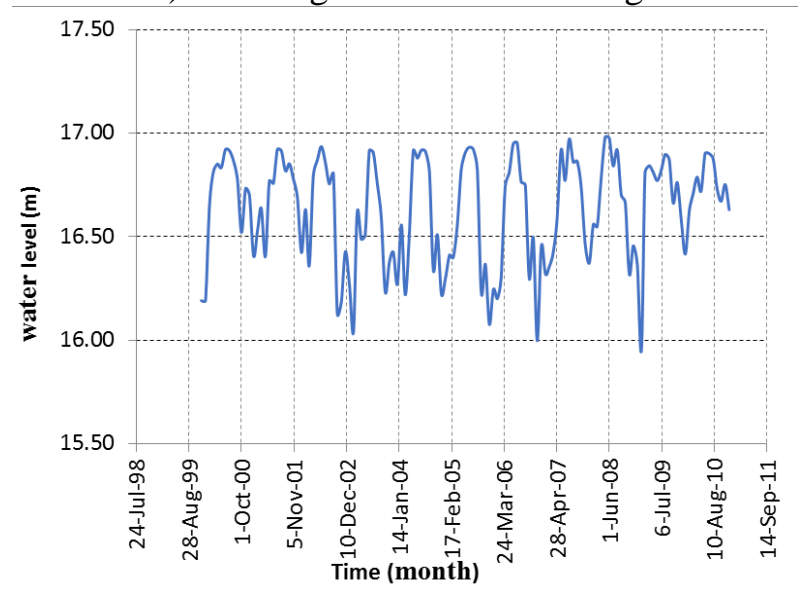

b) The water levels at $\mathrm{Km} 19.00$

Fig. 5. Discharge and the average monthly water levels hydrograph from 2000 to 2010

$$
\begin{aligned}
& \frac{\partial \eta}{\partial t}+\frac{\partial\left(h_{o}+\eta\right) u}{\partial x}+\frac{\partial\left(h_{o}+\eta\right) v}{\partial y}=0 \\
& \frac{\partial u}{\partial t}+\underbrace{u \frac{\partial u}{\partial x}}_{2}+\underbrace{v \frac{\partial u}{\partial y}}_{3}+\underbrace{g \frac{\partial \eta}{\partial x}}_{4}-\underbrace{f v}_{5}+\underbrace{\frac{g u U}{c^{2}\left(h_{o}+\eta\right)}}_{6}-\underbrace{\frac{F_{x}}{\rho_{w}\left(h_{o}+\eta\right)}}_{7}-u \underbrace{\left(\frac{\partial^{2} u}{\partial x^{2}}+\frac{\partial^{2} u}{\partial y^{2}}\right)}_{8}=0 \\
& \underbrace{\frac{\partial u}{\partial t}}_{1}+\underbrace{u \frac{\partial u}{\partial x}}_{2}+\underbrace{v \frac{\partial u}{\partial y}}_{3}+\underbrace{g \frac{\partial \eta}{\partial y}}_{4}-\underbrace{f u}_{5}+\underbrace{\frac{g v U}{c^{2}\left(h_{o}+\eta\right)}}_{6}-\underbrace{\frac{F_{x}}{\rho_{w}\left(h_{o}+\eta\right)}}_{7}-\underbrace{u\left(\frac{\partial^{2} v}{\partial x^{2}}+\frac{\partial^{2} v}{\partial y^{2}}\right)}_{8}=0
\end{aligned}
$$

In which (valid for both $\mathrm{x}$ - and $\mathrm{y}$-direction):1 (Velocity gradient), 2 (Velocity gradient), 2\&3 (Advection terms), 4(Pressure gradient), 5 Coriolis 
'force'), 6(Friction term), 7(External forcing (e.g. waves and wind), 8 (Viscosity term), $f$ ( Coriolis force),C (Chezy coefficient), $\mathrm{F}_{\mathrm{X}}$ (External forcing in $\mathrm{x}$-direction) and Fy (External forcing in $\mathrm{x}$-direction).

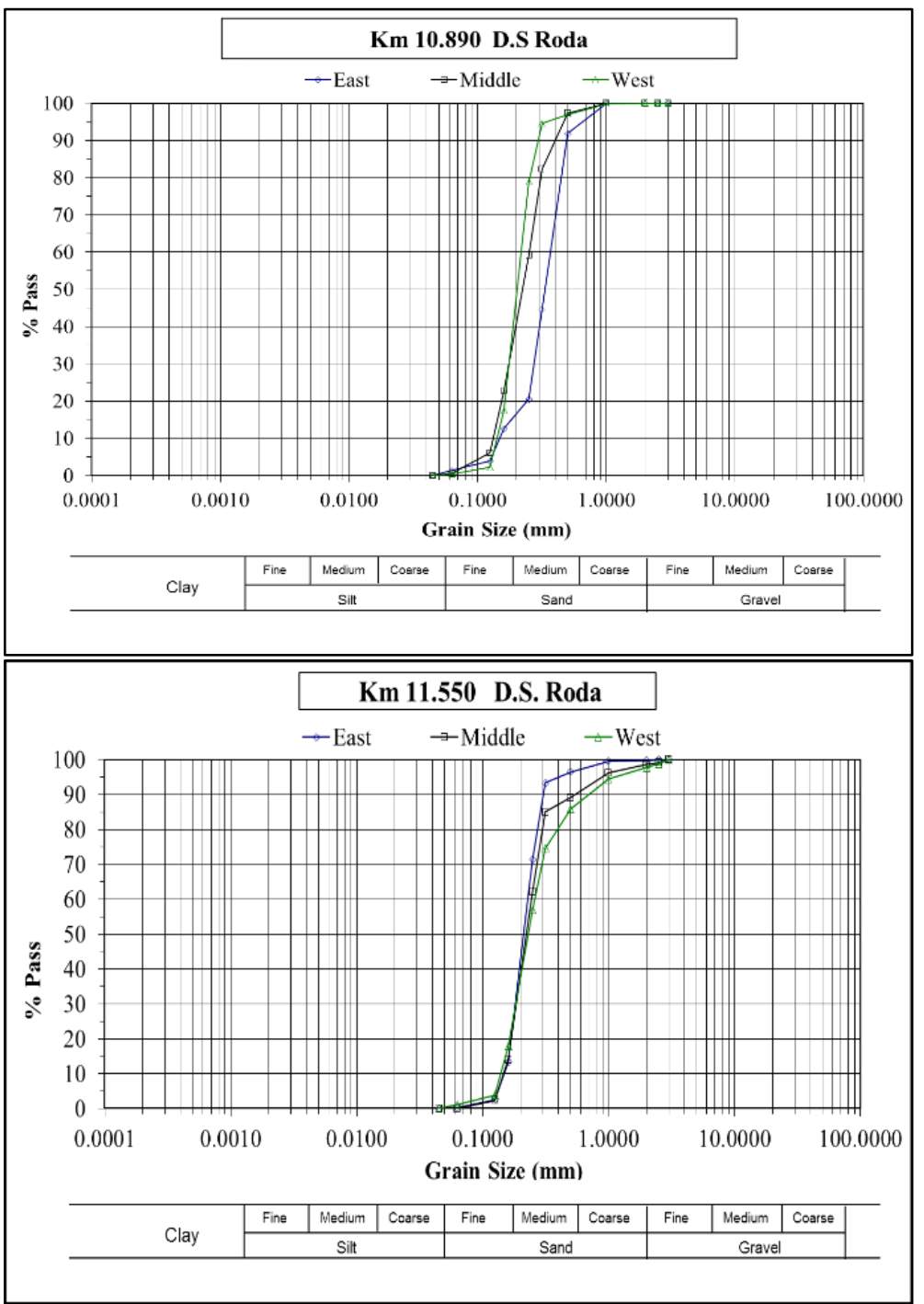

Fig. 6. Grain size accumulation curves

\subsubsection{Grid Generation}

Using the contour map, the land boundary for the study area grid was generated by the "RGF grid" module in Delft 3D. The grid covered an area of $12 \mathrm{Km}^{2}$, with a distance of $8.3 \mathrm{~km}$ along the shoreline. A fine grid $(50 \mathrm{~m} * 60 \mathrm{~m})$. The grid used in the model is presented in Figure (7). 

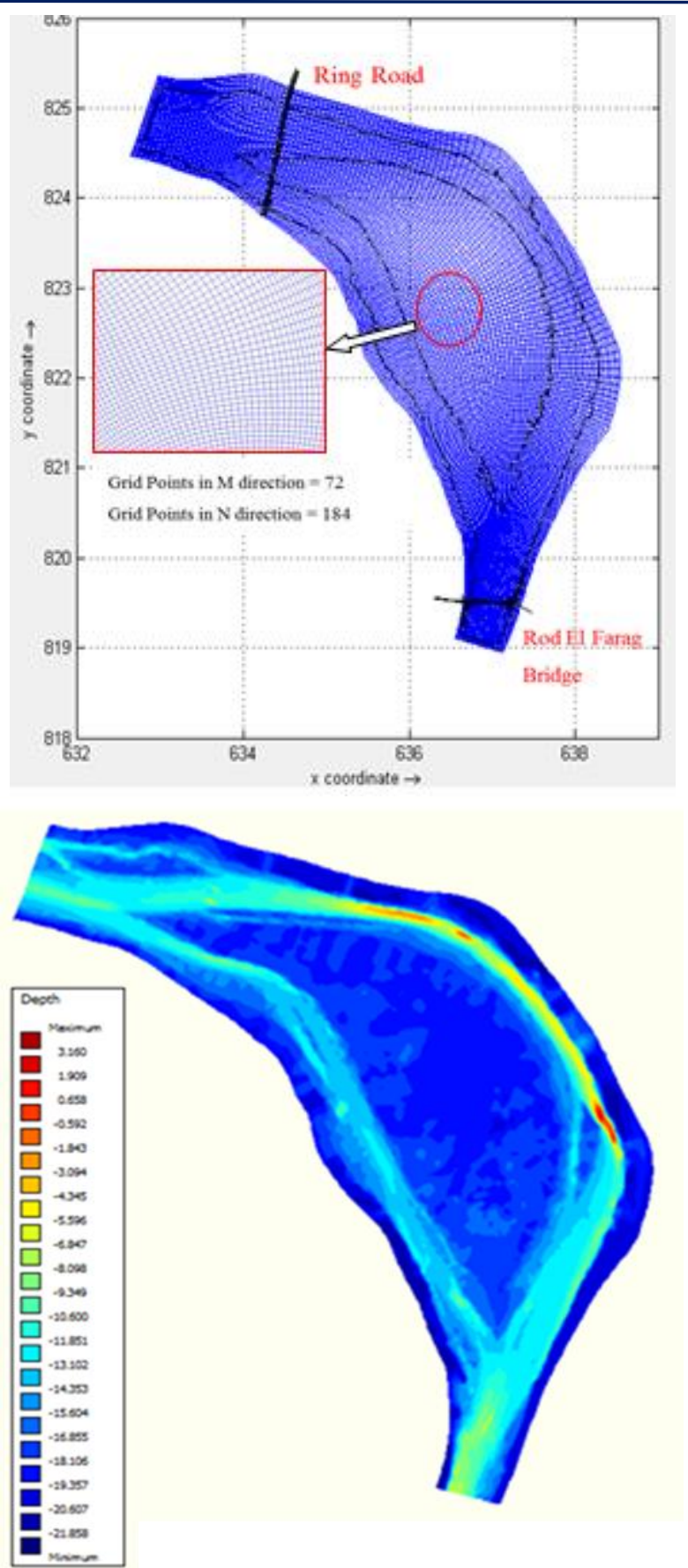

Fig. 7. Study reach grid elements and bathymetry data

\subsection{Calibration Processes}

The calibration process is generally made to assure that model behaves as nature, so that, the discharge was measured along the reach under 
investigation. A discharge, of 100 million $\mathrm{m}^{3} /$ day (corresponding to the time of velocity measurements in 2006) was used as a boundary condition just upstream of the study area. Also, the corresponding water stage of (16.46) m was used as a downstream boundary condition.

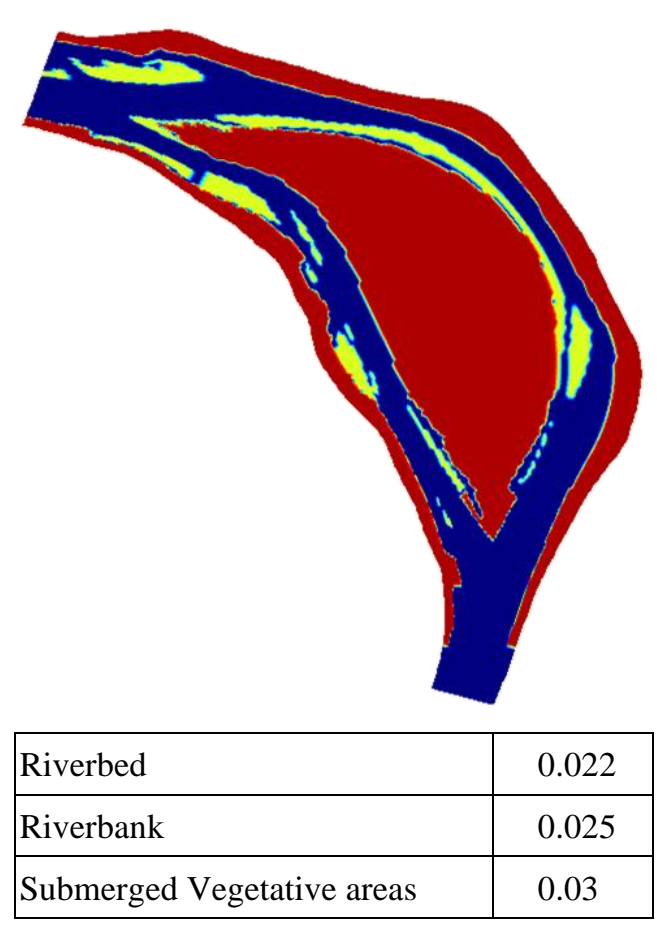

Fig. 8. Roughness coefficient range and velocity calibration

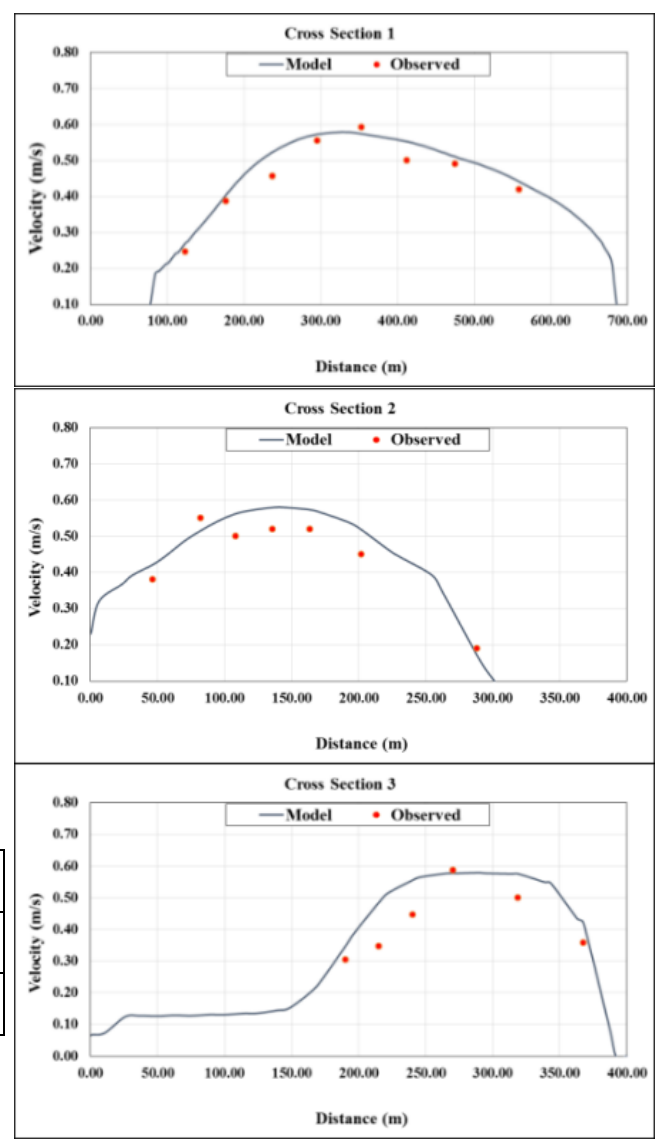

The calibration and verification of the model depend on adopting the roughness values that are if there is a coincidence between both measured and predicted flow velocity. Figure (8) shows a map representing values of manning's roughness for different types and comparisons between measured and predicted velocities. The root mean square error (RMSE), represented by equation no. (4), is calculated between the predicted and measured depth average velocities, the optimum value of RMSE is zero means that model gives perfect results as nature, but this value almost never resulted in any simulation, the RMSE for this simulation is 0.043 which approaching zero value, which indicates that model is well-calibrated and represents the natural flow condition to high extents. 


$$
R M S E=\sqrt{\frac{\sum_{t=1}^{n}\left(A_{t}-F_{t}\right)^{2}}{n}}
$$

Where $A_{t}=$ the actual value, $F_{t}=$ the forecast value, $\mathrm{n}=$ the number of observations

\section{Results and analysis}

\subsection{The morphological changes for the study area}

To identify the morphological changes that occurred for the southern part of Warrak island (island nose), the historical contour maps for both 1982 and 2003, in addition to recent 2019 hydrographic survey for the study reach are used. Five cross-sections were created in the southern part showing the bed and island, to evaluate the morphological changes as in Figure (9). Generally, the southern end of the island has a significant change in the bed levels in the period from 1982 to 2003, but the change in these bed levels from 2003 to 2019 is a slight change.

\subsection{Alternatives solutions plans}

As indicated in the objectives, the southern nose of Warrak Island will be subjected to total or partial removal to help in increasing the efficiency of the western channel around warrak island to convey more flow and increase the carrying capacity, and hence decreasing the sedimentation in this branch. Also, to study the effect of dredging of this branch to safe navigation depth $(12.66 \mathrm{~m})$ as well. The calibration case is used as a reference case that represents the current situation of the flow. In addition, seven cases the previously illustated in Figure (4) and Table (1).

Hydrodynamic simulation of the different cases was performed in order to calculate the flow passes through west and east branches. Figure (10) shows the flow passes through both east and west branches resulted from different scenarios. It can be concluded that, The reference case (calibration case) indicates that flow ratio passes through the west channel is $31.4 \%$ of the total flow passes through the main upstream cross-section of the Nile.

It can be concluded, generally, that dredging scenarios $\left(S_{1}, S_{2}, S_{3}\right.$, and $\mathrm{S}_{7}$ ) have a greater effect in increasing flow passes through the west branch. Even the values are very close to each other, the scenario $\left(\mathrm{S}_{3}\right)$, which contains the dredging of the west channel and removing the west part of the island nose, has the maximum flow ratio $(45.52 \%)$ compared with other scenarios. Consequently, the scenario $\left(\mathrm{S}_{3}\right)$ was selected to predict morphological change rates. 

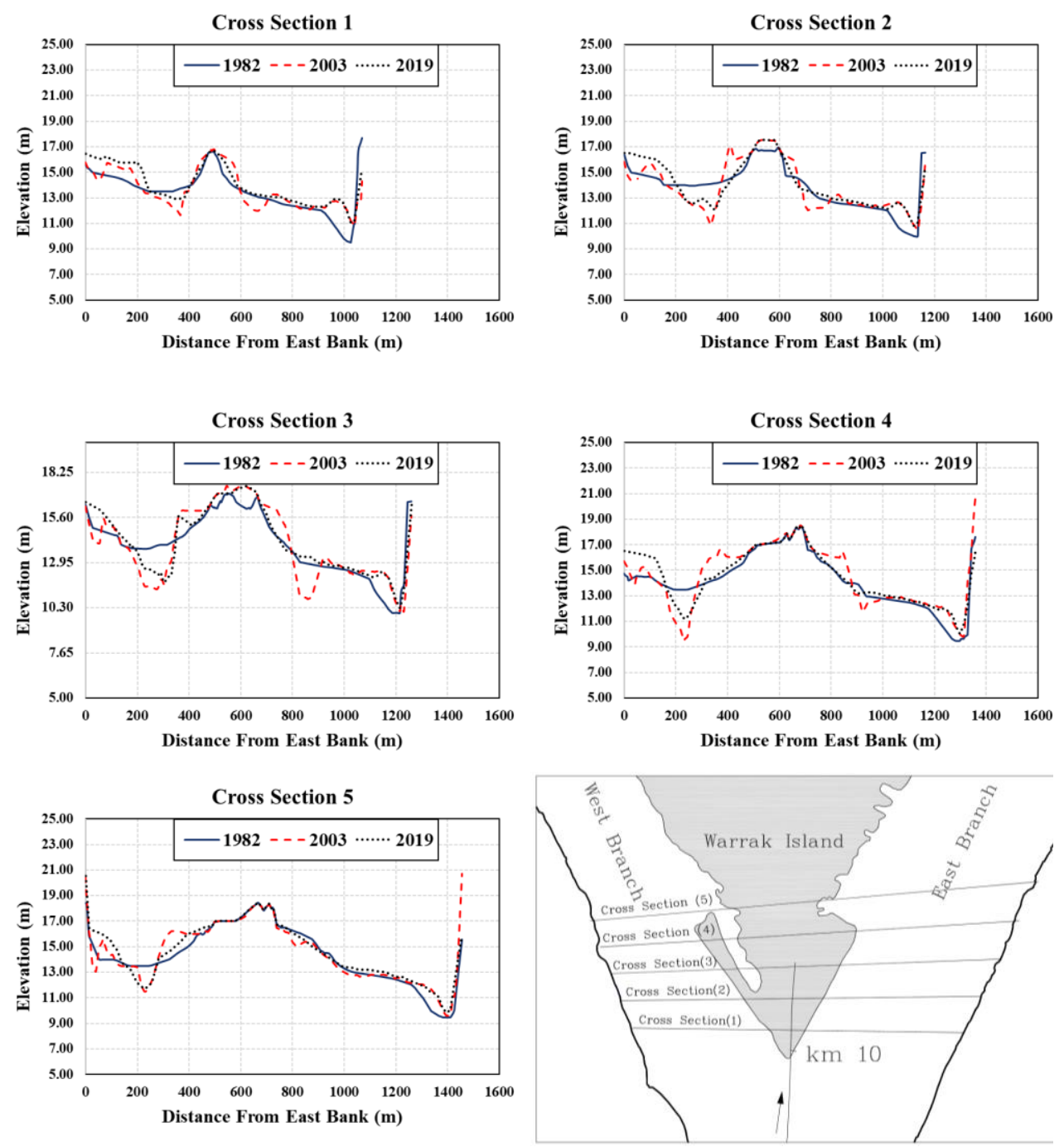

Fig. 9. The morphological changes for years 1982, 2003 and 2019

Morphological simulation is adopted to predict the changes that occurred for the west channel for the next ten years, where the hydrological scenario (flow discharge and water level) were taken as the hydrological pattern, illustrated in Figure (4). To get the effect of the proposed scenario in increasing the efficiency of the west branch, Figure (11) shows the difference in bed elevation every two years compared with the initial case. It is noted that sediment is accumulated at the entrance of the west branch by time. The rate of sediment deposition is calculated every two years, where the rate of sediments could be 0.4 meters for the year from 2020 to $2022,1.6$ meters for the year from 2020 to $2024,1.8$ meters for the year from 2020 to $2026,2.8$ meters for the year from 2020 to 2028 and 3 meters for the year from 2020 to 
2030 respectively. On the contrary, the rate of erosion for the western channel could be 0.4 meters for the year from 2020 to 2022, 0.8 meters for the year from 2020 to 2024, 0.8 meters for the year from 2020 to 2026, 1 meter for the year from 2020 to 2028 and 1 meter for the year from 2020 to 2030 respectively.

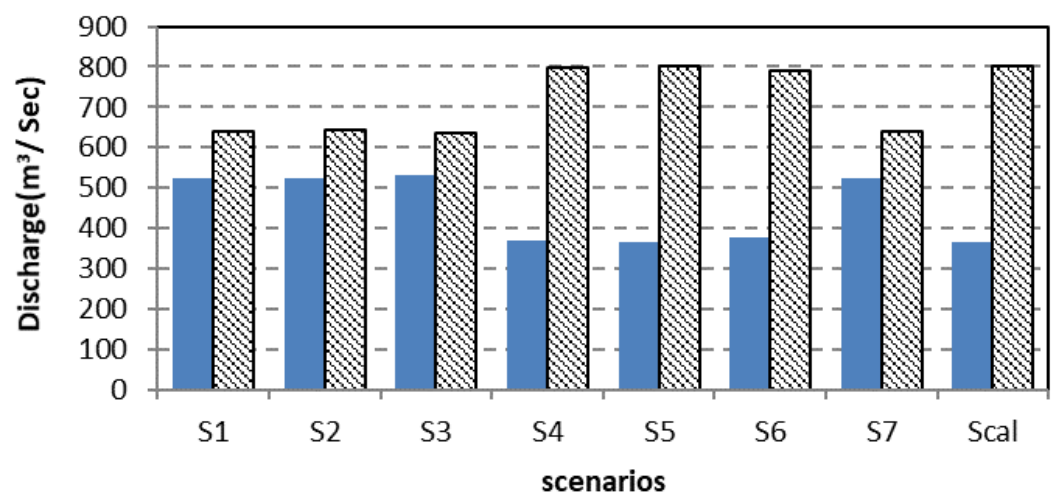

- West Channel East Channel

Fig. 10. Flow passes in both east and west branch for different scenarios
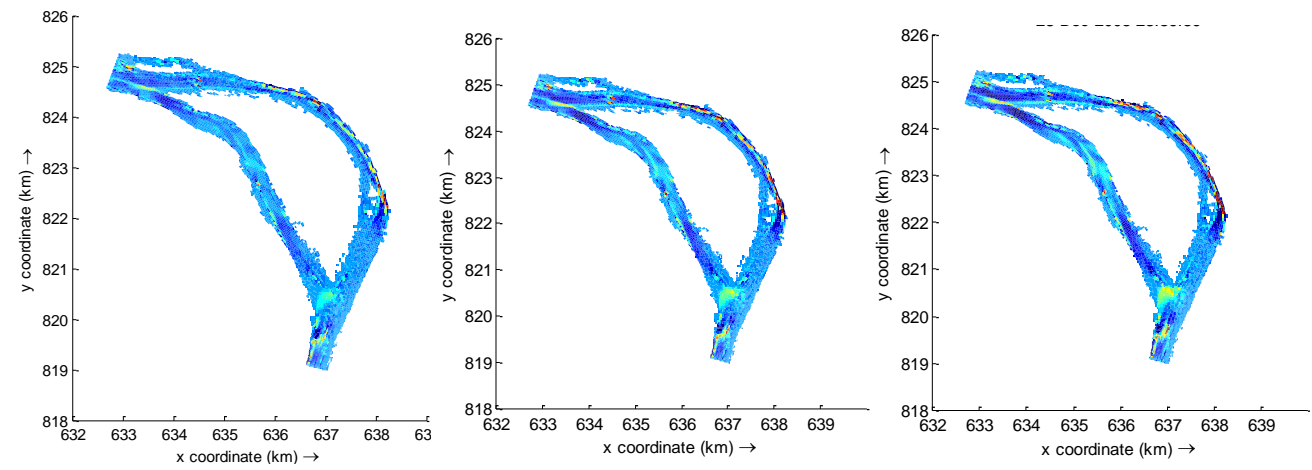

From year 2020 to 2022

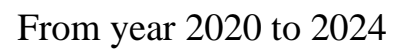

From year 2020 to 2026
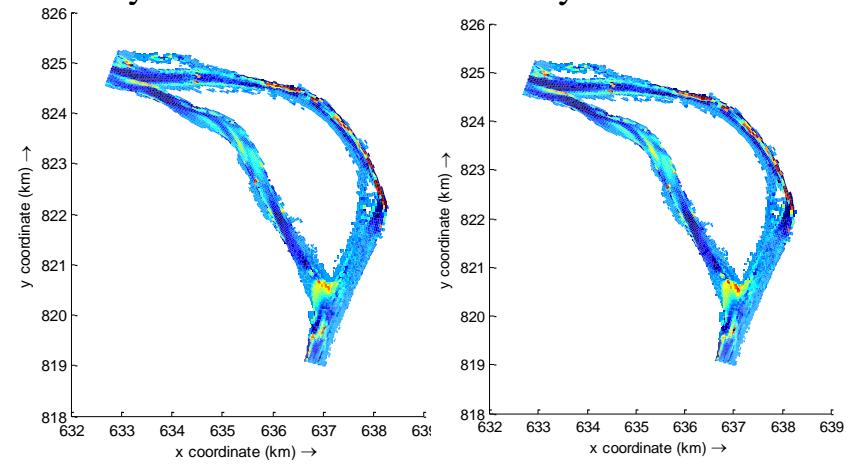

From year 2020 to 2028 From year 2020 to 2030

Fig. 11. Prediction of Warrak Island sediment rate 
The development of the west branch was proposed to canalize the branch to reduce its cross-section area, so that, it can convey the low flow discharge without making any sedimentation problems. There are two scenarios, were tested, with the development plan; the first is without making any changes or dredging works in bed elevation of the west channel. While in the second scenario a dredging works were proposed.

The results of the two proposed development scenarios are given in Figure (12). For the first scenario, where only a canalization of the branch has been done, Figure (12a) indicates that sedimentation occurred at the entrance of the west branch, and along the branch, there is no significant change, as shown. For the second scenario, when dredging and canalization occurs, it is noted that the entrance of the branch is subjected to sedimentation too, as indicated in Figure (12b), while the rest of the branch the bed elevation still has value less than the safe navigation level $(12.66 \mathrm{~m})$, except at two locations which can be treated periodically with dredging.

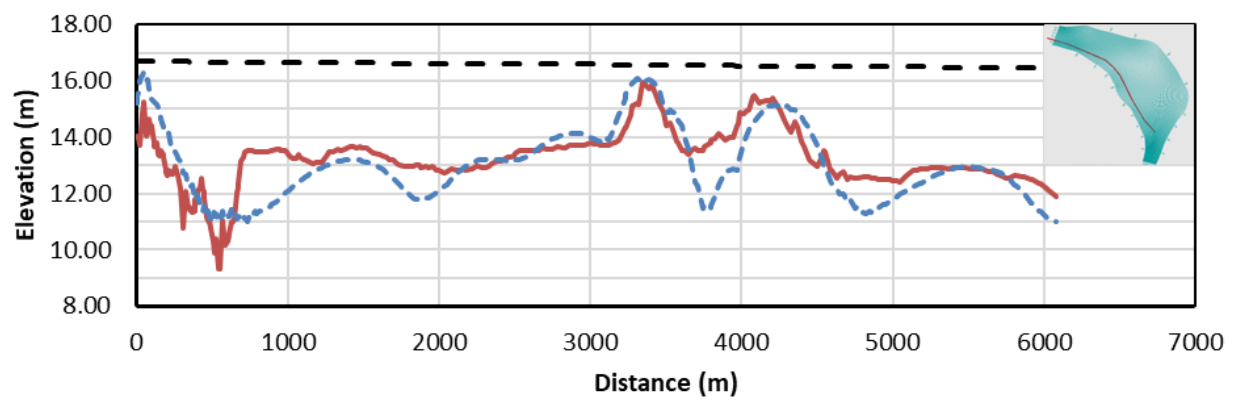

—Current Bed $2020 \quad$ - - - - Predicted Bed 2030 - W Water Surface Elevation

a- Comparison between current bed (2020) and predicted bed (2030) without development

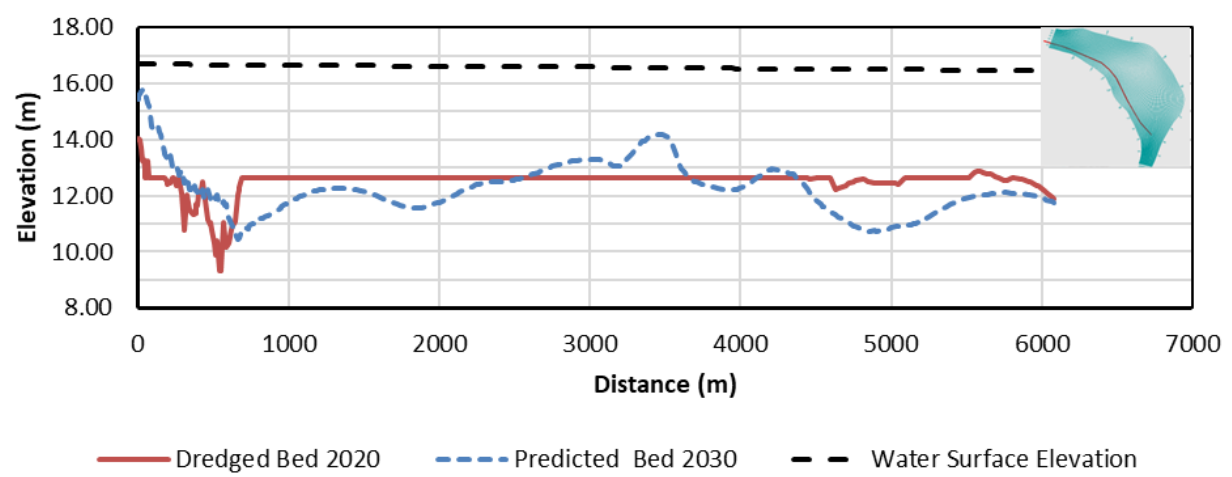

b- Comparison between current bed (2020) and predicted bed (2030) with development

Fig. 12. Current and development of the bed level with and without dredging 


\section{Conclusions and Recommendations}

The southern part (nose) of the island is subject to unmanaged human intervention, which may affect the flow distribution between both east and west branches. A 2D model (Delft3D) was used to predict the hydraulic and morphologic changes that occurred. Eight scenarios were proposed to increase the flow ratio, and hence increase the carrying capacity, in this branch. The scenarios include the total or partial removal of the southern nose (unmanaged intervention) and/or dredging the west branch to safe navigation elevation $(12.66 \mathrm{~m})$. A canalization of the west branch is proposed as development and applied to the original bed and dredged bed.

Results shows that the flow ratio for the west branch is $31.4 \%$ of total flow passes through the Nile for the current case (calibration case). It was also found that when western branch is subjected to dredging, the flow passes through it increases too. where the scenario $S_{3}$ that include removal of the southern part of the island nose and dredging the west branch attract more flow than other dredging cases, where the ratio is about $45.52 \%$ of the total flow.

The morphological changes were predicted for $\mathrm{S}_{3}$ scenario for the next ten years (from 2020 to 2030), it was found that the entrance of the west channel is subject to sedimentation, due to the morphology of the Nile river in this region. Results also indicates, for development scenarios, that deposition also occurred in the entrance of the west branch, like before, but the dredging was limited to few locations, which can be handled with dredging. So, it is recommended, in case of using the west branch for navigation in an emergency case, to follow the development of the west branch as a solution.

\section{References}

[1] W. R. Osterkamp, "Processes of fluvial island formation, with examples from plum creek, Colorado and Snake River, Idaho," Wetlands, 1998, doi: 10.1007/BF03161670.

[2] B. L. Leopold and M. G. Wolman, "River Channe1 Patterns: Braided, Meandering and Straight," USGS Prof. Pap., vol. 282B, pp. 39-85, 1957.

[3] D. Ham and M. Church, "Channel Island and Active Channel Stability in the Lower Fraser River Gravel Reach," Dep. Geogr. Univ. Br. Columbia Vancouver, B.C. V6T 1Z2, 2002.

[4] Y. Raslan and R. Salama, "Development of Nile River islands between Old Aswan Dam and new Esna barrages," Water Sci., vol. 29, no. 1, pp. 77-92, 2015, doi: 10.1016/j.wsj.2015.03.003.

[5] N. Sadek and N. Hekal, "Prediction of the Future Situation of the River Nile," in Twelfth International Water Technology Conference, IWTC12 2008, Alexandria, Egypt 323 PRE, 2008, pp. 323-336. 
[6] A. Moussa, "Morphological Analysis for Reach Four of the Nile River from 1982 to 2004 Using Rating Curves and Hydraulic Geometry Parameters Morphological Analysis for Reach Four of the Nile River from 1982 to 2004 Using located Downstream Assuit Barrage at," Ain Shams J. Civ. Eng. A S J C E, no. March 2010, p. 14, 2019.

[7] R. Mohammed and N. Hekal, "Effect of Aquatic Weeds on Velocity Profile Changes and Island Formation," in Tenth International Water Technology Conference, IWTC10 2006, Alexandria, Egypt, 2006, pp. 337-355.

[8] N. Sadek, "Island development impacts on the Nile River morphology," Ain Shams Eng. J., vol. 4, no. 1, pp. 25-41, 2013, doi: 10.1016/j.asej.2012.06.006.

[9] F. Dawson, "The seasonal effects of aquatic plant growth on the flow of water in a stream," 1978.

[10] J. S. Wood, "David Rumsey Map Collection," J. Am. Hist., 2002, doi: $10.2307 / 3092531$.

[11] D. Wuthrich, "Google Earth Pro," Geospatial Solut., 2006.

[12] Deltares, "Delft3D-FLOW, Simulation of multi-dimensional hydrodynamic flows and transport phenomena, including sediments," User Manual, Delft, Netherlands, 2006. 


\section{زيادة كفاعة المجرى الغربى لجزيرة الوراق على نهر النيل}

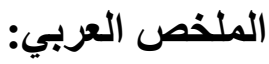

عادة ما تتعرض الأنهار لتغير ات مورفولوجية مستمرة بسبب التدخلات البشرية وحدوث

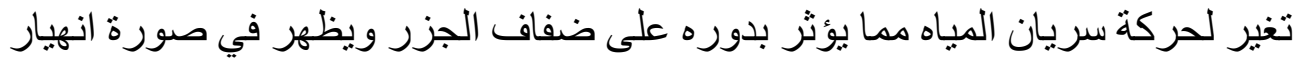

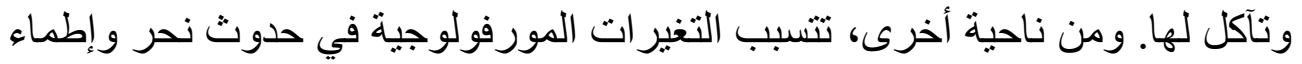

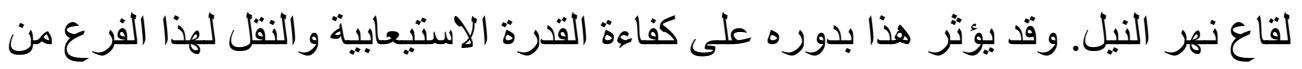

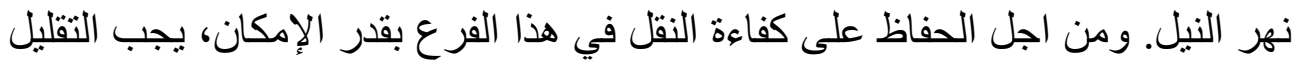

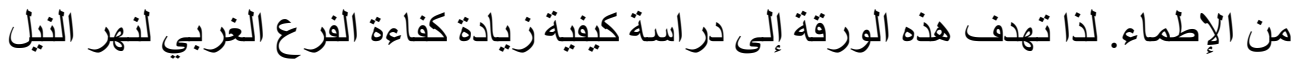

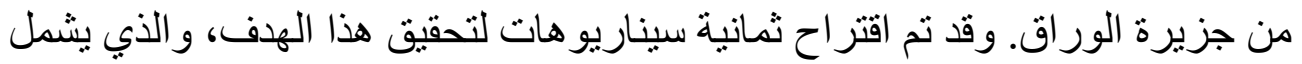

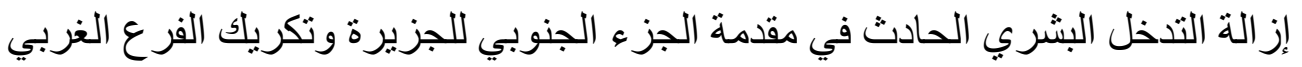

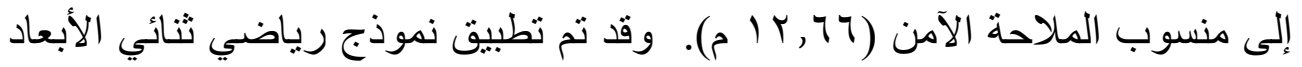

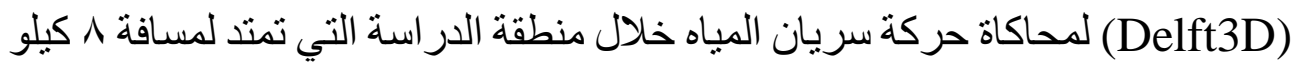

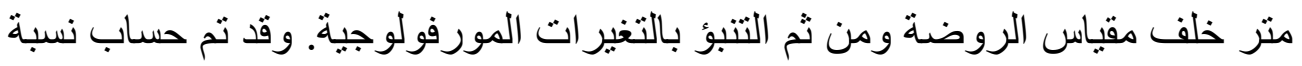

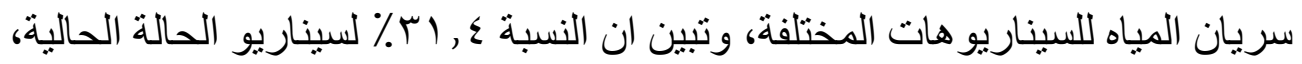

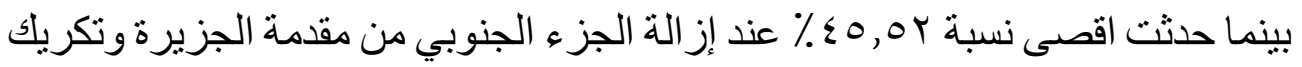
الفرع الغربي.

تم التنبؤ بالتغيرات المورفولوجية ووجد أن مدخل الفرع الغربي يتعرض باستمرار

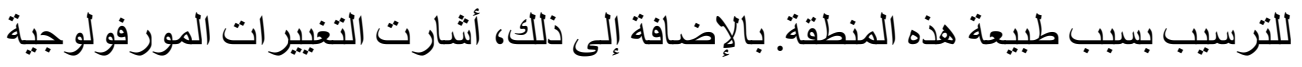

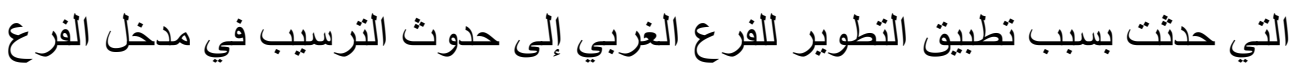

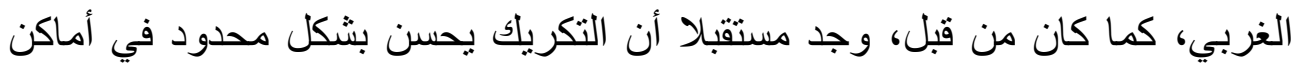

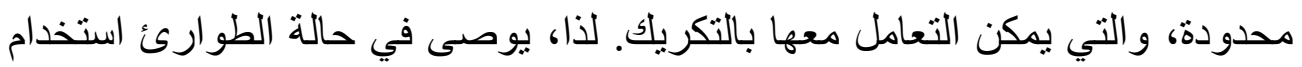

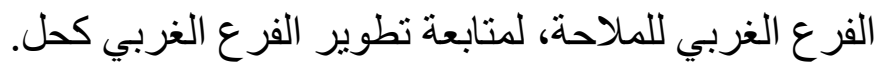

